\title{
Fragments of Local Polyphony in Late Medieval Central Europe: Towards a Semiotic Interpretation of Musical Sources
}

\begin{abstract}
A number of fragments was recently discovered dating from the second quarter of the 15 th century and containing mensural polyphony practised in Central Europe. To date, the particular repertory they preserve has only been known from much later manuscripts in use by the Czech Utraquists. In this chapter, the analysis of these fragments will lead us to investigate why some manuscripts containing Central-European mensural polyphony were destroyed, while others, such as the Utraquist books, were instead preserved. The question of preservation-destruction and the creation of fragments is also approached theoretically by proposing a semiotic interpretation based on the theory by Krzysztof Pomian.
\end{abstract}

Around eighty manuscripts, dating from the period between the end of the fifteenth century and the beginning of the seventeenth century, and containing polyphony written mostly in full black mensural notation are preserved in various collections in the Czech Republic. ${ }^{1}$ This polyphonic repertoire, consisting of Latin songs (cantiones), polytextual motets and Mass sections may be considered 'local', since it is not known from any sources outside Central Europe. The musical features, type of notation, and concordances suggest that it was composed during the first half of the fifteenth century or, in many cases, even earlier. Besides anonymous pieces, there are also works by Petrus Wilhelmi de Grudencz, born in 1392 and active until at least 1452. Therefore, this repertoire is much older

1 See Fisher/Lütolf 1972, 127-315; Graham 2006.

Note: The author gratefully acknowledges funding through the HERA project 'Sound Memories: The Musical Past in Late-Medieval and Early-Modern Europe' (<soundme.eu>). This project has received funding from the European Union's Horizon 2020 research and innovation programme under grant agreement no. 649307. Translated by John Comber.

¿ Open Access. (c) 2020 Pawet Gancarczyk, published by De Gruyter. (c) BY-NC-ND This work is licensed under the Creative Commons Attribution-NonCommercial-NoDerivatives 4.0 International License. https://doi.org/10.1515/9783110717884-007 
than its manuscript transmission, and there are examples of songs and motets which were copied for more than 150 years. Within the context of the music written in the fifteenth and sixteenth centuries, this style of polyphonic singing might be regarded as conservative, even archaic. This would explain why it occupied a marginal place in modern historiography, traditionally focussed instead on describing musical innovation and progress.

The books in question are linked to Bohemia and to the Utraquists, a moderate Hussite faction, and they are most often associated with educated urban citizens belonging to litterati brotherhoods (fraternitates litteratorum), which together with choirboys provided the musical setting for the liturgy in Utraquist churches. ${ }^{2}$ Besides containing polyphony in full mensural notation, the manuscripts preserve Mass chants and monophonic songs in varying proportions; for this reason they tend to be classified as graduals or 'cantionals'. The appearance and contents depended on the wealth of the sponsors and the needs of their users. For example, the Franus Codex (CZ-HK II A 6), completed in 1505 for the Church of the Holy Spirit in Hradec Králové, eastern Bohemia, took the spectacular form of a richly illuminated parchment volume. ${ }^{3}$ Much more modest in appearance is the famous Speciálník Codex (English: 'special codex', CZ-HK II A 7), which was possibly copied in Prague in c.1485-1500. As the name suggests, this codex is not a typical Utraquist manuscript, as its contents are almost wholly polyphonic: both local, conservative repertoire in full mensural notation, and more contemporary repertoire in void mensural notation, including early works by Josquin. ${ }^{4}$

Such a large number of surviving manuscripts from a single region and linked to a particular social group may lead to the assumption that Utraquist Bohemia was the focal point for the cultivation of this polyphonic repertoire. Moreover, there is no reason to deny the special role played by the Utraquists in cultivating polyphony in full mensural notation, to which they were evidently attached and with which they must have identified. However, in this study I would like to focus on surviving fragments in order to argue that the prevailing historiographical views of this phenomenon are distorted. A comprehensive account will have to consider the state of preservation of the sources, what was

2 See Horyna 2006, 117-134.

3 Mráčková [Hlávková] 2009. See also the description: <http://www.manuscriptorium.com/ apps/index.php?direct=record\&pid=AIPDIG-MVCHK_HR_6_II_A_6_0OSL9UC-cs> (accessed 23 May 2019)

4 Mráčková [Hlávková] 2002. See also the description: <http://www.manuscriptorium.com/ apps/index.php?direct=record\&pid=AIPDIG-MVCHK_HR_7_II_A_7_2PGBZM4-cs> (accessed 23 May 2019). 
destroyed during the fifteenth and sixteenth centuries, and what was instead preserved: in the field of fragmentology I believe it is important to reflect on why some manuscripts became waste paper, whilst others were treated with care. My work is guided by the assumption that, in ontological terms, fragmentary sources and complete sources represent two different categories, and that such consideration should also affect the way these are interpreted. I will return to this issue in the second part of the article.

\section{Fragments of Local Polyphony in Central Europe}

The polyphony in Utraquist manuscripts was first studied by Jaromír Černý (19392012). In an extensive study published in 1971, Černý showed that the models of polytextual motets preserved in Bohemia should be sought in the motets from the Engelberg Codex (CH-EN 314), dated to 1372/73. ${ }^{5}$ In later work, Černý linked the genesis of some cantiones to the conductus tradition. ${ }^{6}$ A link connecting Utraquist manuscripts with those older repertoires was established by manuscripts from the turn of the fifteenth century, especially the so-called Trnava Manuscript (H-Bn lat. 243, c.1400), probably from Moravia, ${ }^{7}$ and a manuscript from the Cistercian monastery of Vyššì Brod in southern Bohemia (CZ-VB 42, c.1410). According to Černý, motets and songs of such distant origins were adapted and rearranged in Czech lands, also coming to form the basis for a more 'modern' output in the fifteenth century. During the second half of that century, they filtered through into the Utraquist repertoire, where they survived over the following decades. ${ }^{8}$ From Bohemia, then, this music spread to neighbouring regions.

Since the time of Černý's research, the pool of sources of local polyphony has grown, especially with regard to fifteenth-century manuscripts. Familiar sources have been reinterpreted and shown in new contexts. Today, one can distinguish among them a group of fragments, ranging from single leaves to larger sets, linked by common features. This list is certainly not complete and may well increase thanks to further research (see Table 1).

5 Černý 1971 and Černý 1972.

6 Černý 1984.

7 Černý 1971, 10-11.

8 Hlávková 2020. 
Table 1: Fragments of local polyphony in Central Europe 1420-1460.

\begin{tabular}{|c|c|c|c|}
\hline Siglum & $\begin{array}{l}\text { Provenance } \\
\text { (suggested) }\end{array}$ & No. of folios & Repertoire / Composers \\
\hline CZ-UO A $3^{9}$ & Bohemia & $34 \mathrm{ff}$. & $\begin{array}{l}\text { cantiones, motets, Mass sections, } \\
\text { chant / Petrus Wilhelmi }\end{array}$ \\
\hline D-Gs XXX, $1^{10}$ & Silesia & $30 \mathrm{ff}$. & $\begin{array}{l}\text { cantiones, motets, Mass sections, } \\
\text { chant / Petrus Wilhelmi }\end{array}$ \\
\hline H-Bn lat. $534^{11}$ & Spiš & $6 \mathrm{ff}$. & $\begin{array}{l}\text { cantiones, motets, rotula, Mass } \\
\text { section / Petrus Wilhelmi }\end{array}$ \\
\hline H-Bu U.Fr.l.ch. $299^{12}$ & Slovakia & $1 \mathrm{f}$. & cantiones \\
\hline PL-GD $2153 a^{13}$ & Gdańsk & $2 \mathrm{ff}$. & motets, cantio, rotulum \\
\hline PL-Kj $2188^{14}$ & Kraków & $1 \mathrm{f}$. & cantiones \\
\hline PL-Wn BOZ 64a ${ }^{15}$ & Mazovia & $2 \mathrm{ff}$. & $\begin{array}{l}\text { cantiones, chant / Nicolaus?, Petrus } \\
\text { Wilhelmi }\end{array}$ \\
\hline PL-WRu I F $269^{16}$ & Silesia & $2 \mathrm{ff}$. & cantiones, rotulum / Petrus Wilhelmi \\
\hline PL-WRu IV Q $223^{17}$ & Silesia & $2 \mathrm{ff}$. & textless compositions (cantiones?) \\
\hline PL-WRu XV Q $1066 a^{18}$ & Silesia & $1 \mathrm{f}$. & motet, cantiones \\
\hline
\end{tabular}

The date of these fragments is hard to establish, yet judging by the handwriting, watermarks, and repertoire, none of them dates from before 1420 or after 1460 . They belong, therefore, to the period before the Utraquist repertoire had taken shape, when in Central Europe full mensural notation was gradually giving way to void notation. In some instances, it is difficult to determine the provenance of these sources; it goes without saying that the provenance of a fragment is not necessarily identical to that of the host book. However, even if we take the various possibilities into account, it is abundantly clear that these fragments come from quite a large area of Central Europe: Upper Hungary (present-day

\footnotetext{
9 Brewer 1984, II, 520-525. For dating of the fragments see Gancarczyk 2017, 8-9.

10 Staehelin 2001.

11 Rajeczky 1972.

12 Brewer 1990, 15-17.

13 Zwolińska 2000, 53-60; Gancarczyk 2013, 49-50.

14 Brewer 1984, II, 359-360, 542.

15 Szyller 1996, 109-116.

16 Staehelin 2001, 104-106.

17 Staehelin 2001, 106-108.

18 Gancarczyk 2013.
} 
Slovakia), Bohemia, Silesia, southern Poland, Mazovia and Pomerania. Some of them (H-Bn lat. 534, PL-GD 2153a, PL-Wn BOZ 64a) were found with books used in monasteries, which could shed some light on their possible provenance.

The fragments, however, do not resemble later Utraquist manuscripts; they appear to have once been part of lower grade manuscripts, probably for everyday personal use, produced without the direct support of a sponsor or an institution. The material of the writing support is paper, most frequently in small folio format, less often in quarto. The initials are rather modest, drawn by dilettantes rather than professional artists. Red ink was used to highlight the initials as well as some elements of the notation. The degree of care taken over the notation varies from one fragment to the next, but it never reaches the level of professional calligraphy. As it is common in many fifteenth-century Central European manuscripts, mensural signs are missing. The scribes often left out the clefs, whilst in other cases they adopted a rather liberal approach, giving two clefs at once (in D-Gs XXX,1 and PL-WRu I F 269). ${ }^{19}$ There is instead a consistent use of custodes, most often in the form of a rhombus with two caudae (see Figs 1 and 2), another common feature in Central European mensural manuscripts.

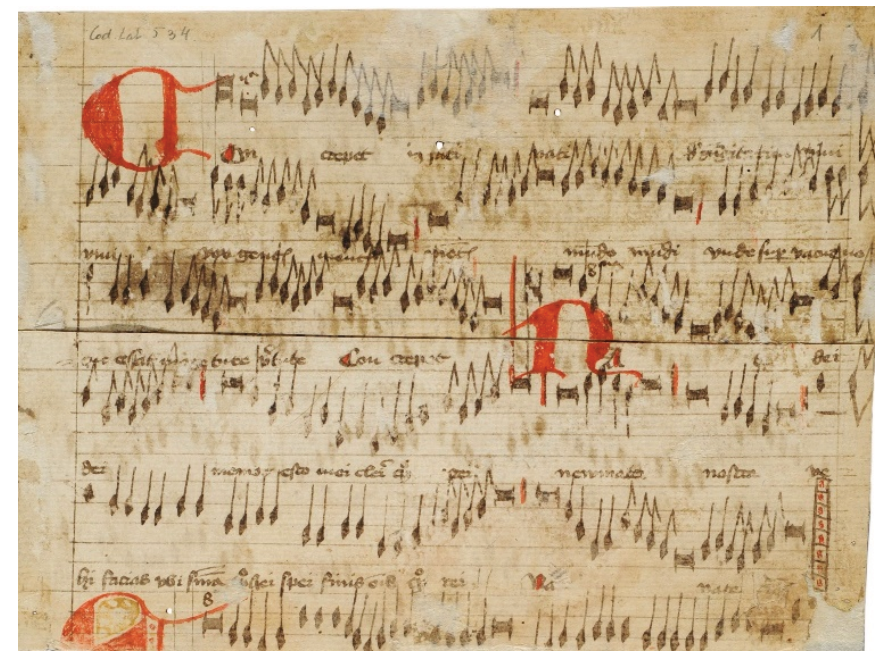

Fig. 1: Budapest, Országos Széchényi Könyvtár, Ms. lat. 534 (H-Bn lat. 534), f. 1r; @ Budapest, Országos Széchényi Könyvtár.

19 On the practice of using clefs in Central Europe, see Schmid 2004, 57-78. 


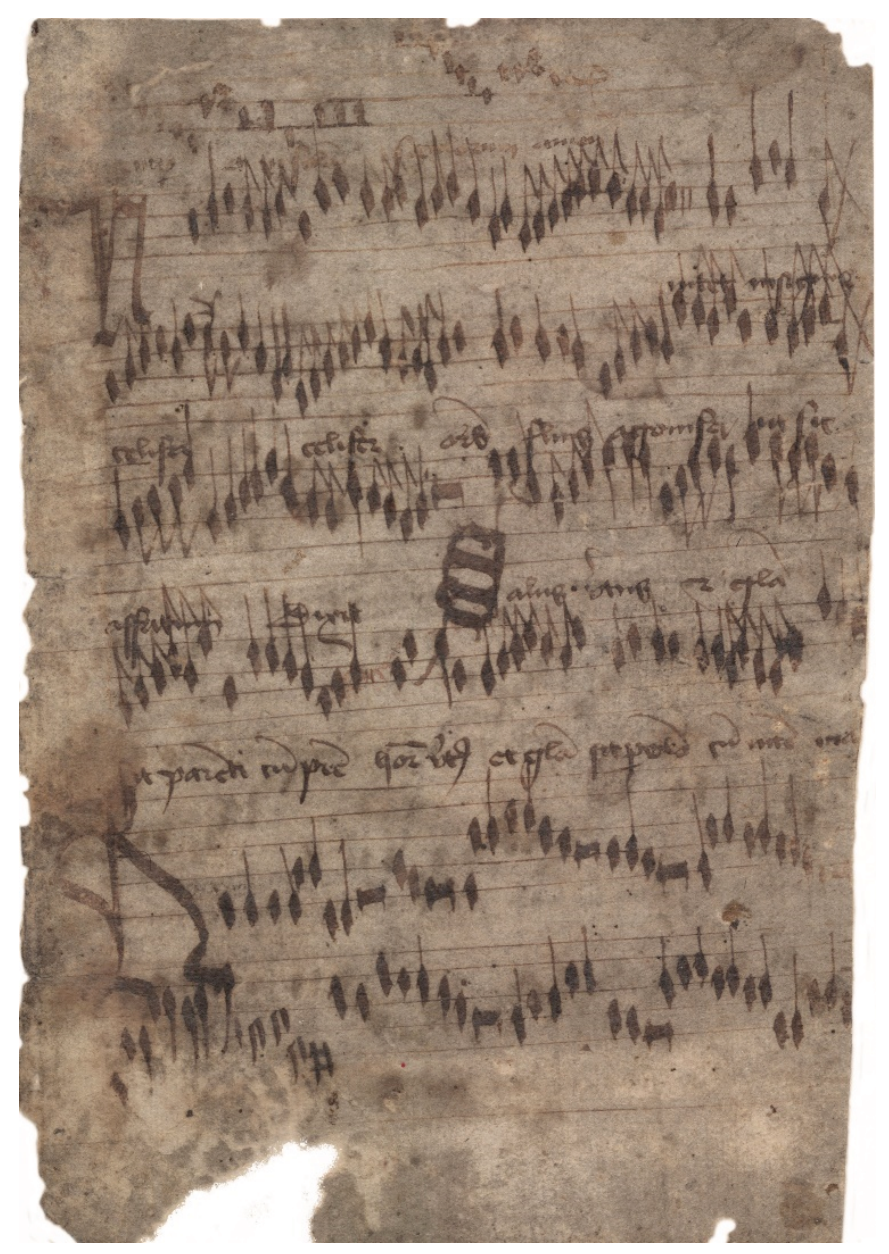

Fig. 2: Warsaw, Biblioteka Narodowa, BOZ 64a (PL-Wn BOZ 64a), f. Ilv; @ Warsaw, Biblioteka Narodowa.

The foliation visible in fragments D-Gs XXX,1 and PL-WRu XV Q 1066a suggests that they were part of larger manuscripts, possibly volumes containing both polyphony in full mensural notation and plainchant (such a combination appears in three fragments, including D-Gs XXX,1). In some fragments, we also find works added in void notation, which reflects the notational changes that occurred in the middle decades of the fifteenth century.

The most crucial element linking all these fragments is the similar repertoire. They contain the same type of compositions as later Utraquist manuscripts. Moreover, one of the fragments (CZ-UO A 3) was produced in the Utraquist 
environment, in eastern Bohemia, but a few decades before the Speciálník Codex - the oldest and most extensive source of this polyphony. This repertoire comprises a trio of genres: cantio, polytextual motet and rotulum. The first two genres are well known, while rotulum denotes a circular canon written in the form of a single melody. In Utraquist manuscripts, rotula were written as polytextual motets; that is, in the form which canon assumes in its climactic phase, when all the parts sing at once. The fragments from the group under discussion include numerous compositions by Petrus Wilhelmi; fragments D-Gs XXX,1, from Silesia and dating from $c .1450$, are among the central sources of his musical output.

Table 2 shows a list of concordances of identified compositions. These are for the most part works from larger sets of fragments held in Ustí nad Orlicí (CZ-UA A 3), Göttingen (D-Gs XXX,1) and Budapest (H-Bn lat. 534), although the content of smaller fragments like single leaves appears to lead to the same conclusions. Of the thirty-three compositions, just one is known from a source dated prior to 1420; that is the motet Voce cordis / Pulchre Syon copied in the Engelberg Codex and, eight decades later, in the fragments CZ-UO A 3. Most of the compositions possess concordances solely with younger manuscripts, dating from after 1460, and for the most part with Utraquist manuscripts, at times very numerous (e.g. Petrus Wilhelmi's song Phonicorum ethicorum).$^{20}$ The list of concordances also includes complete manuscripts produced more or less contemporaneously with our fragments such as the St Emmeram Codex (D-Mbs Clm 14274) - the repertoire of which, besides compositions by Petrus Wilhelmi, includes several anonymous cantiones - and also a recently-discovered manuscript from Opava, in Czech Silesia (CZ-OP RC 4), in which local polyphony appears alongside monophonic passions and lamentations. ${ }^{21}$ In other concordant manuscripts from Kraków (PL-Kj 2464), Trier (D-TR 322/1994), Leipzig (D-Leu 1236), and Bohemia (CZ-TRE A 4) ${ }^{22}$ the musical part appears in an otherwise non-musical context.

20 Such manuscripts as CZ-HK II A 14 and CZ-Pnm AZ 34 date from the turn of the seventeenth century.

21 Welker et al. 2006; Ward 1981, 325-343. On the Opava manuscript see Ciglbauer/Gancarczyk 2017, 99-105.

22 Perz 1973, xxi-xxii, 15-35; Brewer 1990; Ewerhart 1955; Ward 1981, 337-338; Ward 1994, 5473; Weber et al. 1958, 29-53. 
Table 2: List of concordant sources.

\begin{tabular}{|c|c|c|}
\hline Composition & Pre-1460 sources & Post-1460 sources \\
\hline Compangant omnes & CZ-UO A 3, H-Bn lat. 534 & CZ-K 179 \\
\hline $\begin{array}{l}\text { Concrepet infanti / Nate dei / } \\
\text { Exordium quadruplate / } \\
\text { Verbum caro }\end{array}$ & $\begin{array}{l}\text { CZ-UO A 3, H-Bn lat. 534, } \\
\text { PL-Kj } 2464\end{array}$ & $\begin{array}{c}\text { CZ-CH } 12580, \text { CZ-HK II A 6, CZ- } \\
\text { HK II A 7, CZ-Pu } 59 \text { R } 5116\end{array}$ \\
\hline $\begin{array}{l}\text { Congaudemus pariter / En lux } \\
\text { immensa }\end{array}$ & CZ-UO A 3 & $\begin{array}{l}\text { CZ-CH } 12580, \text { CZ-HK II A 6, CZ- } \\
\text { HK II A 7, CZ-KH 88/85, CZ- } \\
\text { KL 403, CZ-Pst 376, CZ-Pn } \\
\text { XIII A 2, CZ-Pu VI B 24, CZ- } \\
\text { Pu } 59 \text { R } 5116\end{array}$ \\
\hline Dies iam letitie & CZ-UO A 3 & CZ-Pn XIII A 2 \\
\hline Ecce renascentis testatur & CZ-UO A 3 & $\begin{array}{l}\text { CZ-Pn I A 17, CZ-Pst 376, CZ- } \\
\text { Pu XVII A 3, CZ-Pu NG 3, CZ- } \\
\text { TAoa, CZ-TEm } 2\end{array}$ \\
\hline Ex stirpe paganorum & $\begin{array}{l}\text { CZ-UO A 3, PL-WRu XV } \\
\text { Q 1066a }\end{array}$ & $\begin{array}{l}\text { CZ-HK II A 6, CZ-CH 12580, CZ- } \\
\quad \text { KH 88/85 }\end{array}$ \\
\hline Genti confer opem & CZ-UO A 3 & $\begin{array}{l}\text { CZ-CH } 12580, \text { CZ-KUm 88/85, } \\
\text { CZ-HK II A } 6\end{array}$ \\
\hline Ihesus Christus nostra salus & CZ-OP RC 4, D-Gs XXX,1 & \\
\hline $\begin{array}{l}\text { Iacob scalam / Pax eterna / } \\
\text { Terribilis } \\
\text { (Petrus Wilhelmi) }\end{array}$ & D-LEu 1236, D-Gs XXX,1 & $\begin{array}{l}\text { CZ-CH 12580, CZ HK II A 6, CZ- } \\
\text { HK II A 7, CZ-KL 403, CZ-Pn } \\
\text { XIII A 2, CZ-Pu } 59 \text { R 5116, }\end{array}$ \\
\hline Laudes dicat omnis & CZ-UO A 3 & CZ-Pst 376, CZ-Pu VI B 24 \\
\hline $\begin{array}{l}\text { Methaphisice saliit / In tempesto } \\
\text { adiit / Ordo naturae }\end{array}$ & CZ-UO A 3 & CZ-HK II A 7 \\
\hline Nicolai solempnia & H-Bn lat. 534 & SK-BRmp Inc. 33 \\
\hline Novus annus adiit & H-Bn lat. 534 & $\begin{array}{l}\text { CZ-CH } 12580, \text { CZ-HK II A 6, CZ- } \\
\text { HK II A 7, CZ-KL } 403\end{array}$ \\
\hline $\begin{array}{l}\text { Panis ecce / Panis ewus / Pange } \\
\text { exul / Patribus / Tantum ergo } \\
\text { (Petrus Wilhelmi) }\end{array}$ & CZ-UO A 3 & $\begin{array}{l}\text { CZ-CH 12580, CZ-HK II A 6, CZ- } \\
\text { HK II A 7, CZ-KUm 88/85, } \\
\text { CZ-Pn XIII A 2, CZ-Pu 59 } \\
\text { R 5116, PL-Kj 8a }\end{array}$ \\
\hline $\begin{array}{l}\text { Paraclitus egrediens } \\
\qquad \text { (Paranymphus adiit) }\end{array}$ & $\begin{array}{c}\text { D-TR } 322 / 1994, \\
\text { H-Bn lat. } 534\end{array}$ & $\begin{array}{l}\text { CZ-CH } 12580, \text { CZ-HK II A 6, CZ- } \\
\text { HK II A 7, CZ-KL 503, CZ- } \\
\text { KUm 88/85, CZ-Pn XIII A 2, } \\
\text { CZ-Pu VI B 24, CZ-Pu } 59 \\
\text { R } 5116\end{array}$ \\
\hline Patrem omnipotentem (Credo) & $\begin{array}{l}\text { D-TR } 322 / 1994, \\
\text { H-Bn lat. } 534\end{array}$ & $\begin{array}{l}\text { A-Wn 5094, D-Z 119,1, } \\
\text { DK-Kar } 687\end{array}$ \\
\hline
\end{tabular}


Table 2 (continued): List of concordant sources.

\begin{tabular}{|c|c|c|}
\hline Composition & Pre-1460 sources & Post-1460 sources \\
\hline $\begin{array}{l}\text { Phonicorum ethicorum } \\
\text { (Petrus Wilhelmi) }\end{array}$ & PL-Wn BOZ 64a & $\begin{array}{l}\text { CZ-CH 12580, CZ-HK II A 6, } \\
\text { CZ-HK II A 7, CZ-HK II A 14, } \\
\text { CZ-KL 403, CZ-Pam 7847, } \\
\text { CZ-Pn IV B 9, CZ-Pn XIII A 2, } \\
\text { CZ-Pnm AZ 34, CZ-Pu 59 } \\
\text { R 5116, CZ-Pu XVII A 32, } \\
\text { CZ-Pu XVII A 53a, } \\
\text { CZ-RY 829/87, CZ-S M-3, } \\
\text { CZ-TEm 2, CZ-VO }\end{array}$ \\
\hline $\begin{array}{l}\text { Pneuma eucaristiarum / Veni vere / } \\
\text { Dator eia / Paraclito tripudia } \\
\text { (Petrus Wilhelmi) }\end{array}$ & D-MERa 13b, D-Gs XXX,1 & $\begin{array}{l}\text { CZ-CH 12580, CZ-HK II A 6, } \\
\text { CZ-HK II A } 7\end{array}$ \\
\hline $\begin{array}{l}\text { Poligena exanimes } \\
\text { (Petrus Wilhelmi) }\end{array}$ & CZ-OP RC 4, D-Gs XXX,1 & \\
\hline $\begin{array}{l}\text { Pomi morsum / Hominem / Sed } \\
\text { paratus / Paraneuma eructemus } \\
\text { (Petrus Wilhelmi) }\end{array}$ & D-Gs XXX,1 & $\begin{array}{l}\text { CZ-CH 12580, CZ-HK II A 6, } \\
\text { CZ-HK II A 7, CZ-KL 403, } \\
\text { CZ-KUm 88/85, } \\
\text { CZ-Pam 7847, CZ-Pn IV B 9, } \\
\text { CZ-Pn XIII A 2, CZ-Pu 59 } \\
\text { R 5116, CZ-Pu VI B 24, } \\
\text { CZ-Pu XVII A 32, CZ-VO }\end{array}$ \\
\hline $\begin{array}{l}\text { Preconia etroclita } \\
\text { (Petrus Wilhelmi) }\end{array}$ & D-Gs XXX,1 & $\begin{array}{l}\text { CZ-CH } 12580, \text { CZ-HK II A 6, } \\
\text { CZ-HK II A } 7\end{array}$ \\
\hline $\begin{array}{l}\text { Predulcis eurus } \\
\text { (Petrus Wilhelmi) }\end{array}$ & $\begin{array}{l}\text { CZ-OP RC 4, CZ-TRE A 4, } \\
\text { D-Mbs Clm 14274, } \\
\text { PL-WRu I F } 269\end{array}$ & CZ-CH 12580, CZ-HK II A 7 \\
\hline $\begin{array}{l}\text { Presidiorum erogatrix } \\
\text { (Petrus Wilhelmi) }\end{array}$ & D-Gs XXX,1 & $\begin{array}{l}\text { CZ-CH } 12580, \text { CZ-HK II A 6, } \\
\text { CZ-HK II A } 7\end{array}$ \\
\hline $\begin{array}{l}\text { Presulem ephebeatum } \\
\text { (Petrus Wilhelmi) }\end{array}$ & $\begin{array}{l}\text { D-LEu 1236, D-Mbs } \\
\text { Clm } 14274, \mathrm{H}-\mathrm{Bn} \\
\text { lat. } 534\end{array}$ & $\begin{array}{l}\text { CZ-CH } 12580, \text { CZ-HK II A 6, } \\
\text { CZ-HK II A 7, CZ-Pn XIII A 2, } \\
\text { CZ-Pu } 59 \text { R 5116, CZ-Pu VI } \\
\text { C 20a, D-F Fragm. lat. VII } 20\end{array}$ \\
\hline $\begin{array}{l}\text { Probleumata enigmatum } \\
\text { (Petrus Wilhelmi) }\end{array}$ & CZ-TRE A 4, CZ-UO A 3 & $\begin{array}{l}\text { CZ-CH 12580, CZ-HK II A 6, } \\
\text { CZ-HK II A 7, CZ- } \\
\text { KUm 88/85, D-Z 17.8.39 }\end{array}$ \\
\hline Procedentem sponsum & CZ-UO A 3, H-Bn lat. 534 & $\begin{array}{l}\text { CZ-HK II A 15, CZ-Pu V H 11, } \\
\text { CZ-Pu VI G 10a }\end{array}$ \\
\hline Resonet in laudibus & CH-SGs 392, CZ-UO A 3 & \\
\hline Resultet gens angelica & CZ-UO A 3 & $\begin{array}{l}\text { CZ-CH } 12580, \text { CZ-HK II A 6, } \\
\text { CZ-HK II A } 7\end{array}$ \\
\hline
\end{tabular}


Table 2 (continued): List of concordant sources.

\begin{tabular}{|c|c|c|}
\hline Composition & Pre-1460 sources & Post-1460 sources \\
\hline $\begin{array}{l}\text { Salve domina / Recordare virgo / } \\
\text { Alma redemptoris }\end{array}$ & D-Gs XXX,1, PL-GD 2153a & $\begin{array}{l}\text { CZ-CH 12580, CZ-HK II A 7, } \\
\text { CZ-HK II A } 6\end{array}$ \\
\hline $\begin{array}{l}\text { Sophia nasci fertur / O quam } \\
\text { pulchra / Magi videntes }\end{array}$ & CZ-UO A 3 & $\begin{array}{c}\text { CZ-CH 12580, CZ-HK II A 6, } \\
\text { CZ-HK II A 7, CZ-K 179, } \\
\text { CZ-KL 403, CZ-Pn XIII A } 2\end{array}$ \\
\hline Surrexit Christus hodie & CZ-UO A 3 & CZ-CH 12580 \\
\hline Voce cordis / Pulchre Syon & CH-EN 314, CZ-UO A 3 & \\
\hline [Unidentified] & $\begin{array}{l}\text { D-Gs XXX,1, PL-WRu IV } \\
\text { Q } 223\end{array}$ & \\
\hline
\end{tabular}

The remarks set out above lead to the following conclusions: before the Utraquist manuscripts were produced, their polyphonic repertoire in full mensural notation was familiar also beyond Bohemia, across the area that we call Central Europe. The provenance of the fragments from the period 1420-1460, as well as of the complete manuscripts mentioned here, suggests that this repertoire was cultivated in monastic and university circles. ${ }^{23}$ Previous research into the songs of Petrus Wilhelmi revealed that this repertoire, adopted by the Utraquists during the second half of the fifteenth century, sometimes functioned independently within the Catholic tradition..$^{24}$ Its perception as being very strongly linked to post-Hussite Bohemia stems from the specific information provided by the sources. This, however, does not necessarily reflect the actual state of affairs, since we should bear in mind that Utraquist manuscripts were protected more than earlier monastic and university manuscripts, which were destroyed just a few decades after they were produced, as demonstrated by from the dating of the host books.

\section{Towards a Semiotic Interpretation of Musical Sources}

At this point, we should ask how some manuscripts came to be preserved for centuries whilst others were destroyed. What did late medieval communities wish to

23 We should certainly link the preparation of manuscripts D-Mbs Clm 14274, PL-Kj 2464, and D-Leu 1236 to a university environment; see above footnotes 21 and 22.

24 Gancarczyk 2017. 
preserve for posterity and what did they discard? The rational explanation that more expensive, more carefully produced and presentable manuscripts were safeguarded more than cheaper manuscripts belonging to 'pragmatic literacy'25 seems insufficient and does not seem to match with the facts. If we remain within the sphere of the manuscript sources we discussed here, and follow this line of reasoning, one could only wonder why an elegant parchment manuscript containing works by Du Fay and Petrus Wilhelmi (D-MERa 13b) was destroyed, whilst a sloppy student notebook (PL-Kj 2464), a bane for editors today, was instead preserved. ${ }^{26}$ Equally inadequate is the explanation that it was manuscripts containing out-of-date repertoire or with hindered legibility due to changes in notation that were discarded. If that were the case, then no medieval music manuscript would have come down to us.

In attempting to shed some light on this phenomenon, I would like to turn to the works of Krzysztof Pomian, who proposes a semiotic interpretation of the history of culture. Amongst visible artefacts, Pomian distinguishes five functional classes: bodies (les corps), waste (les déchets), things (les choses), semiophores (les sémiophores) and media (les médias). ${ }^{27}$ He classifies books and all written documents, including - one should assume - musical sources, as semiophores, that is, objects combining a material dimension with a semiotic dimension. Semiophores are visible objects bearing meaning that refers us to what cannot be seen. It goes without saying that every music manuscript refers to the invisible domain, but its semiotic dimension is not confined solely to the visual representation of the world of sounds: it often possesses additional meanings, on account of which the manuscript itself is looked after, regardless of whether it is being used in the musical practice, or instead excluded from that use. It is precisely such a set of meanings and values which prevents - saves - the manuscript object (as semiophor) from becoming simply a thing (chose): in our case, waste paper.

Utraquist manuscripts were something more than merely collections of words and music that could be read. They were an important part of the identity and representation of a specific social group: urban Bohemians belonging to litterati brotherhoods. Significantly, in the iconography of those fraternities, an open book of music is placed at the centre of the image: the fellows are not

25 See Keller 1992.

26 On D-MERa 13b see Fischer 1964, 92-94. Despite the best efforts, many works from PL-Kj 2464 have not been satisfactorily read and edited; see Brewer 1990. Many problems are also posed by D-TRs 322/1994; see Ewerhart 1955, 21-105, and Lubieniecki 2019, 91-98.

27 Pomian 1999, 200-208. 
singing from it, but presenting it. ${ }^{28}$ Utraquist manuscripts retained their significance even after the progressive re-Catholicisation of Bohemia during the seventeenth century. In 1783, when Emperor Joseph II issued a decree abolishing litterati brotherhoods, on the basis of which their property was confiscated and put up for sale, urban citizens bought up the books which their predecessors had funded. One of the graduals from Hradec Králove contained an inscription informing readers that it had been purchased by the townsfolk 'for themselves and for generations to come'. ${ }^{29}$ Towards the end of the nineteenth century, 'outlawed' brothers were still inscribing their names and professions, as well as the date on which they joined the brotherhood, on the pages of a manuscript from Vodñany in southern Bohemia (CZ-VO).

Books excluded from practical use but belonging to some collection - such as D-Mbs Clm 14274 from the collection of Hermann Pötzlinger, donated to St Emmeram monastery in Regensburg - also remained semiophores. ${ }^{30}$ Adding a book to a monastery or university library ensured its preservation, since all collections are by nature of semiotic significance. ${ }^{31}$ This was probably also the reason behind the survival of the above-mentioned miscellanea manuscripts (i.e. PLKj 2464 and D-TRs 322/1994), which in themselves form small collections of a sort, since besides the musical 'addenda' they contain homiletic, grammatical or philosophical texts. The fragments of local polyphony listed in Table 1 were not so fortunate; they ceased to be semiophores when they lost their utilitarian function of bearing a musical repertoire. In this instance, the exclusion from practical use resulted in their discarding or - abandoning our present-day 'destruction' narrative - in something 'useless' being turned into something 'useful'.

It should be stressed that an object's possession of a semiotic dimension does not guarantee its survival. Indeed, it exposes that object to great danger from individuals and institutions hostile to the meanings invested in it. History abounds in examples of books being destroyed for ideological reasons: they went from being semiophores to things (e.g. waste paper) or, in the more dramatic cases, waste (e.g. ashes). ${ }^{32}$ For this reason, during the Reformation, masses of medieval fragments were produced in Scandinavia. ${ }^{33}$ During the seventeenth and eighteenth centuries, Jesuit censors removed pages containing texts linked to the

28 Graham 2006, 628-629, Plates 10, 12, and 14.

29 CZ-HK II A 13a, f. 4r; see Graham 2006, 58.

30 Rumbold/Wright 2009, 201-248.

31 Pomian 1987, 53.

32 See Bosmajian 2006.

33 See Heikkilä/Ommundsen 2017. See also in this book Sanna Raninen's chapter, 185-203. 
cult of Jan Hus from Utraquist books. ${ }^{34}$ In 1944, the German Brandkommando ('fire command') in Warsaw burned priceless collections of books housed in the Krasiński Family Library. ${ }^{35}$ Thousands of manuscripts lost forever included PLWn F.I.378 (dated to c.1440), containing works by Antonio Zacara da Teramo, Johannes Ciconia and Mikołaj Radomski. ${ }^{36}$

Our view of musical culture is, to a considerable extent, contaminated by the circumstance that some sources have been preserved, because they have remained semiophores, while others have been destroyed, which equated to depriving them of their semiotic significance. The size of the losses increased due to accidental cataclysms, such as fires and floods. In many cases, it is difficult to establish what exactly caused particular manuscripts to be turned into waste paper, yet it seems necessary to reflect on such questions. Going back to Pomian's categories, for many generations now, especially thanks to collectors and scholars, membra disiecta musicae have turned from things into semiophores. Yet, while we can certainly study their actual physical form, a large part of that which cannot be seen still remains concealed to us.

\section{List of sources}

A-Wn 5094

CH-EN 314

CH-SGs 392

CZ-CH 12580

CZ-HK II A 6

CZ-HK II A 7

CZ-HK II A 13a

CZ-HK II A 14

CZ-HK II A 15

CZ-K 179

CZ-KH 88/85

CZ-KL 403

CZ-OP RC 4

CZ-Pam 7847
Vienna, Österreichische Nationalbibliothek, Cod. 5094

Engelberg, Benediktinerkloster, Musikbibliothek, MS 314 ('Engelberg Codex')

Sankt Gallen, Stiftsbibliothek, MS 392

Chrudim, Regionální muzeum, MS 12580

Hradec Králové, Muzeum východních Čech, MS II A 6 ('Franus Codex')

Hradec Králové, Muzeum východních Čech, MS II A 7 ('Speciálník Codex')

Hradec Králové, Muzeum východních Čech, MS II A 13a

Hradec Králové, Muzeum východních Čech, MS II A 14

Hradec Králové, Muzeum východních Čech, MS II A 15

Český Krumlov, Státní oblastní archiv v Třeboni, pobočka Český Krumlov, MS Kaplanské knihovny 179

Kutná Hora, České muzeum stříbra, rkp. sign. 88/85

Klatovy, Vlastivědné muzeum Dr. Hostaše, MS 403

Opava, Slezské zemské muzeum, MS RC 4

Prague, Archiv hlavního města Prahy, MS 7847

34 Graham 2006, 124-128.

35 Nastulczyk 2016, 464-465.

36 Perz 1973, xxvi-xxix, 103-160. A pre-war photographic copy of this manuscript has come down to us. 


CZ-Pn I A 17
CZ-Pn IV B 9
CZ-Pn XIII A 2
CZ-Pnm AZ 34
CZ-Pst 376
CZ-Pu 59 R 5116
CZ-Pu V H 11
CZ-Pu VI B 24
CZ-Pu VI C 20a
CZ-Pu VI G 10a
CZ-Pu XVII A 3
CZ-Pu XVII A 32
CZ-Pu XVII A 53a
CZ-Pu NG 3
CZ-RY 829/87
CZ-S M-3
CZ-TAoa
CZ-TEm 2
CZ-TRE A 4
CZ-UO A 3
CZ-VB 42

CZ-VO
Prague, Knihovna Národního muzea, MS I A 17

Prague, Knihovna Národního muzea, MS IV B 9

Prague, Knihovna Národního muzea, MS XIII A 2

Prague, Národní muzeum - České muzeum hudby, AZ 34

Prague, Národní archiv, MS 376

Prague, Národní knihovna ČR, Hudební oddělení, 59 R 5116

Prague, Národní knihovna ČR, MS V H 11

Prague, Národní knihovna ČR, MS VI B 24

Prague, Narodní knihovna ČR, MS VI C 20a

Prague, Národní knihovna ČR, MS VI G 10a

Prague, Národní knihovna ČR, MS XVII A 3

Prague, Národní knihovna ČR, MS XVII A 32

Prague, Národní knihovna ČR, MS XVII A 53a

Prague, Národní knihovna ČR, MS NG 3

Rychnov nad Kněžnou, Muzeum Orlických hor, 829/87

Sedlčany, Městské muzeum, MS M-3

Tábor, Státní okresní archiv, MS s.s.

Teplice, Regionální muzeum, Knihovna, MS 2 (olim MS B)

Třeboň, Státní oblastní archiv, MS A 4

Ustí nad Orlicí, Státní okresní archiv, MS A 3

Vyšší Brod, Knihovna cisterciáckého kláštera, MS 42 ('Hohenfurter Liederhandschrift')

Vodňany, Městké muzeum a galerie, inv. 18551

D-F Fragm. lat. VII 20 Frankfurt am Main, Stadt- und Universitätsbibliothek, Fragm. lat. VII 20

D-Gs XXX,1

D-LEu 1236

D-Mbs Clm 14274

D-MERa $13 \mathrm{~b}$

D-TR 322/1994

D-Z 17.8.39

D-Z 119,1

DK-Kar 687

H-Bn lat. 243

H-Bn lat. 534

H-Bu U.Fr.l.ch.299

PL-GD 2153a

PL-Kj 2188

PL-Kj 2464

PL-Kj 8a

PL-Wn F.I.378

PL-Wn BOZ 64a

PL-WRu I F 269

PL-WRu IV Q 223

PL-WRu XV Q 1066a

SK-BRmp Inc. 33
Göttingen, Niedersächsiche Staats- und Universitätsbibliothek, Handschriften und Seltene Drucke, Nachlass Ludwig XXX,1

Leipzig, Universitätsbibliothek, MS 1236

Munich, Bayerische Staatsbibliothek, Clm 14274 ('St Emmeram Codex’)

Merseburg, Domstiftsbibliothek, Hs. 13b

Trier, Stadtbibliothek, MS 322/1994

Zwickau, Ratsschulbibliothek, MS 17.8 .39 (olim 84,2)

Zwickau, Ratsschulbibliothek, MS 119,1

Copenhagen, Det Arnamagnæanske Institut, MS AM 687B, $4^{\circ}$

Budapest, Országos Széchényi Könyvtár, Cod. lat. 243

Budapest, Országos Széchényi Könyvtár, Cod. lat. 534

Budapest, Eötvös Loránd Tudományegyetem Egyetemi Könyvtár,

U.Fr.l.ch.299

Gdańsk, Polska Akademia Nauk - Biblioteka Gdańska, MS 2153a

Kraków, Biblioteka Jagiellońska, MS 2188

Kraków, Biblioteka Jagiellońska, MS 2464

Kraków, Biblioteka Jagiellońska, MS 8a

Warsaw, Biblioteka Narodowa, MS F.I.378 (lost)

Warsaw, Biblioteka Narodowa, MS BOZ 64a

Wrocław, Biblioteka Uniwersytecka, MS I F 269

Wroctaw, Biblioteka Uniwersytecka, MS IV Q 223

Wrocław, Biblioteka Uniwersytecka, XV Q 1066a

Bratislava, Miestne Pracovisko Matice Slovenskej, Inc. 33 (lost) 


\section{References}

Bosmajian, Haig A. (2006), Burning books, Jefferson, NC: McFarland.

Brewer, Charles E. (ed.) (1990), Collectio cantilenarum saeculi XV rkp. Biblioteki Jagiellońskiej Kj 2464, Kraków: PWM Edition.

Brewer, Charles E. (1990), 'The Historical Context of Polyphony in Medieval Hungary: An Examination of Four Fragmentary Sources', in Studia Musicologica, 32: 5-21.

Brewer, Charles E. (1984), The Introduction of the ars nova into East Central Europe: A Study of Late Medieval Polish Sources, 2 vols, PhD dissertation, The City University of New York.

Černý, Jaromír (1971), K nejstarším dějinám moteta včeských zemích [On the earliest history of the motet in Czech lands] (Miscellanea musicologica 24), Prague: Karolinum.

Černý, Jaromír (1972) 'Die mehrtextige Motette des 14. und 15. Jahrhunderts in Böhmen', in Rudolf Pečman (ed.), Colloquium Musica Bohemica et Europaea Brno 1970 (Colloquia on the History and Theory of Music at the International Musical Festival in Brno 5), Brno: International Musical Festival, 71-88.

Černý, Jaromír (1984), 'Vícehlasé písně konduktového typu v českých pramenech 15. stoletî’ [Polyphonic songs of the conductus type in Czech sources of the 15th century], in Miscellanea musicologica, 31: 39-142.

Ciglbauer, Jan, and Pawet Gancarczyk (2017), 'Manuscript RC 4 from the Silesian Museum in Opava and an Unknown Song by Petrus Wilhelmi de Grudencz', in Muzyka, 62/2: 99-105.

Ewerhart, Rudolf (1955), Die Handschrift 322/1994 der Stadtbibliothek Trier als musikalische Quelle (Kölner Beiträge zur Musikforschung 7), Regensburg: Bosse.

Fischer, Kurt von (1964), 'Neue Quellen zur Musik des 13., 14. und 15. Jahrhunderts', in Acta musicologica, 36: 92-94.

Fisher, Kurt von, and Max Lütolf (eds) (1972), Handschriften mit mehrstimmiger Musik des 14., 15. und 16. Jarhunderts (Répertoire International des Sources Musicales B IV³), Munich: Henle.

Gancarczyk, Pawet (2017), 'Changing Identities of Songs by Petrus Wilhelmi de Grudencz', in Hudební věda, 54/1: 5-24.

Gancarczyk, Pawet (2013), 'A New Fragment of 15th-Century Polyphony in Silesia and the Tradition of the Central-European Repertoire', in Pawet Gancarczyk, Lenka Hlávková-Mráčková, and Remigiusz Pośpiech (eds) The Musical Culture of Silesia before 1742. New Contexts New Perspectives, Frankfurt am Main: Peter Lang, 45-54.

Graham, Barry F. H. (2006), Bohemian and Moravian Graduals 1420-1620, Turnhout: Brepols. Heikkilä, Tuomas and Åslaug Ommundsen (2017), 'Piecing Together the Past: The Accidental Manuscript Collections of the North', in Åslaug Ommundsen and Tuomas Heikkilä (eds), Nordic Latin Manuscript Fragments: The Destruction and Reconstruction of Medieval Books, London: Routledge, 1-23.

Hlávková, Lenka (2020), 'Using the Past, Shaping the Present: Tracing the Tradition of Specific Polyphonic Repertories in Bohemian Utraquist Sources (c.1450-1540)', in Karl Kügle (ed.), Sounding the Past: Music as History and Memory, Turnhout: Brepols, 199-213.

Horyna, Martin (2006), 'Vicehlasá hudba v Čechách v 15. a 16. století a její interpreti’ [Polyphony in fifteenth- and sixteenth-century Bohemia and its performers], in Hudební věda, 43/2: 117-134. 
Keller, Hagen (1992), 'Pragmatische Schriftlichkeit im Mittelalter. Erscheinungsformen und Entwicklungsstufen. Einführung zum Kolloquium in Münster, 17.-19. Mai 1989', in Hagen Keller, Klaus Grubmüller, and Nikolaus Staubach (eds), Pragmatische Schriftlichkeit im Mittelalter. Erscheinungsformen und Entwicklungsstufen, Munich: Wilhelm Fink, 1-7.

Lubieniecki, Ryszard (2019), 'Epulemur in azimis from the Manuscript D-TRs 322/1994: An Attempted Reconstruction in the Form of a Circular Canon', in Muzyka, 64/3: 91-98.

Mráčková [Hlávková], Lenka (2009), 'Codex Franus - a Mirror of the Musical Practice of the Bohemian Utraquist Church around 1500?', in Journal of the Alamire Foundation, 1: 79-85. Mráčková [Hlávková], Lenka (2002) 'Kodex Speciálník. Eine kleine Folio-Handschrift böhmischer Provenienz', in Hudební věda, 39/2-3: 163-84.

Nastulczyk, Tomasz (2016), 'Two Centuries of Looting and the Grand Nazi Book Burning. The Dispersed and Destroyed Libraries of the Polish-Lithuanian Commonwealth: Historical Losses and Contemporary Attempts at Reconstruction', in Flavia Bruni and Andrew Pettegree (eds), Lost Books. Reconstructing the Print World of Pre-Industrial Europe, Leiden: Brill, 464-465.

Perz, Mirosław (ed.) (1973) Sources of Polyphony up to c.1500. Facsimiles (Antiquitates Musicae in Polonia 13), Warsaw and Graz: PWN-Polish Scientific Publishers and Akademische Druck- und Verlagsanstalt.

Pomian, Krzysztof (1987), Collectionneurs, amateurs et curieux. Paris, Venise: XVIe-XVIIle siècle, Paris: Gallimard.

Pomian, Krzysztof (1999), 'Histoire culturelle, histoire des sémiophores', in Krzysztof Pomian, Sur l'histoire, Paris: Gallimard.

Rajeczky, Benjamin, (1972), 'Ein neuer Fund zur mehrstimmigen Praxis Ungarns im 15. Jahrhundert', in Studia Musicologica, 14: 147-168.

Rumbold, Ian, and Peter Wright (2009), Hermann Pötzlinger's Music Book. The St Emmeram Codex and its Contexts, Woodbridge: Boydell \& Brewer.

Schmid, Bernhold (2004), “'Rozpaczliwy rozgardiasz z kluczami”. Użycie kluczy w kodeksie menzuralnym St. Emmeram w świetle środkowoeuropejskiej teorii muzyki' ['A desperate confusion of clefs'. The use of clefs in the St Emmeram Codex in the light of Central European music theory], in Muzyka, 49/2: 57-78.

Staehelin, Martin (2001), Neues zu Werk und Leben von Petrus Wilhelmi. Fragmente des mittleren 15. Jahrhunderts mit Mensuralmusik im Nachlaß von Friedrich Ludwig (Nachrichten der Akademie der Wissenschaften in Göttingen 1; Kleinüberlieferung mehrstimmiger Musik vor 1550 im deutschen Sprachgebiet III), Göttingen: Vanderhoeck \& Ruprecht.

Szyller, Stawomir (1996), 'Nieznana średniowieczna kompozycja muzyczna z rękopisu Biblioteki Narodowej BOZ 64' [The unknown medieval musical composition from the National Library BOZ 64 manuscript], in Muzyka, 45/3: 109-116.

Ward, Tom R. (1981), 'A Central European Repertory in Munich, Bayerische Staatsbibliothek, Clm 14274', in Early Music History, 1: 325-343.

Ward, Tom R. (1994), 'Music in the Library of Johannes Klein', in John Kmetz (ed.), Music in the German Renaissance. Sources, Styles, and Contexts, Cambridge: Cambridge University Press, 54-73.

Weber, Jaroslav, Josef Třǐška, and Pavel Spunar (1958), Soupis rukopisů v Třeboni a v Českém Krumlově [A catalogue of manuscripts in Třeboň and Český Krumlov], Prague: NČSAV. 
Welker, Lorenz, et al. (eds) (2006), Der Mensuralcodex St. Emmeram: Faksimile der Handschrift Clm 14274 der Bayerischen Staatsbibliothek München. Kommentar und Inventar von Ian Rumbold unter Mitarbeit von Peter Wright. Einführung von Martin Staehelin (Elementa Musicae 2), Wiesbaden: Reichert.

Zwolińska, Elzbieta (2000), 'Fragmente mit mehrstimmiger Musik des 15. Jahrhunderts aus dem Zistersienserkloster in Oliwa', in Musica Baltica. Danzig und die Musikkultur Europas, Gdańsk: Wydawnictwo Akademii Muzycznej, 53-60. 
